http://jmscr.igmpublication.org/home/ ISSN (e)-2347-176x ISSN (p) 2455-0450

crossref DOI: https://dx.doi.org/10.18535/jmscr/v8i11.60

\title{
A Prospective Study of Etiology of Classical Puo in a Tertiary Care Hospital Located in Northern Andhra
}

\author{
Authors \\ Dr P.S.R.Aneesh ${ }^{1}$, Dr S.Sreenivas ${ }^{2}$, Dr K.Harikrishna ${ }^{3}$, Dr D.Subhash ${ }^{4}$ \\ ${ }^{1,3,4}$ Post Graduate, General Medicine, Andhra Medical College, Visakhapatnam \\ ${ }^{2}$ Professor and Head of Department of General Medicine, Andhra Medical College, Visakhapatnam
}

\begin{abstract}
Background: Pyrexia of unknown origin (PUO) is a diagnostic dilemma in clinical practice. Despite the proper accessibility of different investigations, still diagnosis cannot be reached. The aim of the study was to determine the causes of PUO in a tertiary care hospital located in Northern Andhra.

Materials and Methods: This study was a prospective observational study done in the department of General Medicine in tertiary care Hospital over period of 10 months from November 2019 to august 2020. All patients who satisfied the inclusion criteria and exclusion criteria were taken into the study.

Results: out of 100 patients 65 were male and 35 were female. Infectious causes found to be the most common cause out of which Tuberculosis was most common; followed by neoplasms and then connective tissue disorders.

Conclusion: The most common cause of PUO in this study was infectious causes (Tuberculosis). Undiagnosed cases are still problematic condition that needs exhaustive investigations.

Keywords: PUO- pyrexia of unknown origin, Tuberculosis, Neoplasms, Connective tissue disorders.
\end{abstract}

\section{Introduction}

Fever is a common presenting symptom in clinical practice. PUO is defined as an illness of $>3$ weeks duration with fever $\geq 38.3^{0} \mathrm{C}\left(\geq 101^{0} \mathrm{~F}\right)$ on two occasions and an uncertain diagnosis despite 1 week of inpatient evaluation. Most of the fevers were readily diagnosed based on history and symptom directed physical examination. Additionally, Routine blood investigations such as complete blood counts, complete urine examination, Qbc for malarial parasite, are necessary to establish a definitive diagnosis'

The causes of PUO can be divided into four categories: infective, neoplastic, connective tissue disorders and miscellaneous. The relative importance of each cause has changed over time, with an increasing fraction of patients who remain undiagnosed, which can be up to $51 \%$ of cases. However, in many cases the cause for failure of diagnosis is lack of a proper protocol for investigation. If the investigation is based on the clinical findings, most of the cases can be easily diagnosed. The causes of fever change with the geographical distribution as also with time. Durackand Street classified PUO into Classical, Nosocomial, Neutropenic, HIV PUO. 
Table 1 : Durack and Street classification of PU0 (1991) modified*

\begin{tabular}{|c|c|c|c|c|}
\hline Category & Classic PUO & Nosocomial PU0 & Neutropenic PU0 & HIV PUO \\
\hline Definition & $\begin{array}{l}>3 \text { wks or }>20 \mathrm{PD} \\
\text { visits or }>3 \text { days of } \\
\text { indoor investigation }\end{array}$ & $\begin{array}{l}>3 \text { days, not present } \\
\text { or incubation on } \\
\text { admission }\end{array}$ & $\begin{array}{l}>3 \text { days, absolute } \\
\text { neutropenia }(<500 \\
/ \mathrm{ml})\end{array}$ & $\begin{array}{l}3 \text { wks of outpatients or } \\
3 \text { days indoor }\end{array}$ \\
\hline Leading causes & $\begin{array}{l}\text { Infections, collagen } \\
\text { vascular disorders, } \\
\text { Cancers }\end{array}$ & $\begin{array}{l}\text { LRTI (lower respiratory } \\
\text { tract infection), UTI, } \\
\text { catheter sepsis, } \\
\text { post operative } \\
\text { complications }\end{array}$ & $\begin{array}{l}\text { Infections but can be } \\
\text { found in only } 50 \%\end{array}$ & $\begin{array}{l}\text { Typical or atypical } \\
\text { mycobacteria, CMV } \\
\text { (cytomegalo virus), } \\
\text { toxoplasma }\end{array}$ \\
\hline Time course of disease & Months & Weeks & Days & Weeks to months \\
\hline $\begin{array}{l}\text { Tempo of } \\
\text { investigations }\end{array}$ & Weeks & Days & Hours & Days to weeks \\
\hline
\end{tabular}

\section{Aims and Objectives}

To determine the causes of classical PUO in a tertiary care hospital located in northern Andhra.

\section{Materials and Methods}

The present prospective study was done for a period of 10 months from November 2019 to August 2020 in the department of general medicine at a tertiary care Hospital in North Andhra. All patients satisfying the inclusion criteria and exclusion criteria are taken into study. A total of 100 patients were included after taking the informed consent.

After taking a detailed history all patients were examined for lymphadenopathy, any skin lesions, any lesions in oral mucosa any nodules, any hepatomegalay, spleenomegaly. Every patient in our study were subjected to preliminary investigations

like complete blood counts, renal function tests, liver function tests, complete urine analysis, blood sugar levels, blood and urine cultures, CRP,QBC for malarial parasite, Screening for HIV, HBSAG, HCV, Widal test and a chest Xray, Mantoux test, Erythrocyte sedimentation ratio. All investigations were sent before starting of antibiotics. However if fever persisted after three days of antibiotics repeat cultures were sent. The decisionto obtain further diagnostic studies was based on abnormalities found in the initial laboratory workup. Abdominal sonography, pelvic sonography, or CT scanning was performed early in the diagnostic process to rule out some common causes of FUO as intra-abdominal abscess or malignancy, depending on the primary evaluation. Invasive procedures like lumbar puncture bone marrow aspiration and bone marrow biopsy, lymph node FNAC and biopsy depending upon the clinical scenario if they are indicated. . All the collected data was arranged using Microsoft excel sheet.

\section{Inclusion Criteria}

All patients aged $>13$ years satisfying the criteria of Classical PUO

Criteria of Classical PUO:

1. Fever $\geq 38.3^{\circ} \mathrm{C}\left(\geq 101^{0} \mathrm{~F}\right)$ on two occasions

2. Duration of fever $>3$ weeks

3. Uncertain diagnosis despite $>2$ OPD visits or $>3$ days of inpatient investigation.

\section{Exclusion Criteria}

- Patients with Known malignancy

- Patients on steroids 
- Patients with HIV infection

- Women in mid menstrual cycle

- Patients taking antitubercular therapy

- Patients with neutropenia

\section{Results}

out of 100 patients 65 were males and 35 were females. Male to female ratio is $1.85: 1$.

\begin{tabular}{|l|c|c|}
\hline Sex & Number of patients & percentage \\
\hline Male & 65 & $65 \%$ \\
\hline Female & 35 & $35 \%$ \\
\hline Total & 100 & $100 \%$ \\
\hline
\end{tabular}

Out of 100 patients, 86 were diagnosed, whereas 14 were discharged without definite diagnosis. Out of 86 cases most common cause was infectious causes (53) followed by neoplasms (18\%)and then connective tissue disorders (12\%) and then Miscellaneous causes (3); the most common infection being Tuberculosis (24) followed by abscesses(7).

\begin{tabular}{|l|c|}
\hline Diagnostic category & Number of cases \\
\hline INFECTIONS & 53 \\
\hline Tuberculosis & 27 \\
\hline Abscesses & 10 \\
\hline Bacterial endocarditis & 7 \\
\hline Enteric fever & 5 \\
\hline Urinary tract infection & 4 \\
\hline NEOPLASMS & \\
\hline Non Hodgkins lymphoma & 8 \\
\hline Hodgkins lymphoma & 4 \\
\hline Acute myeloid leukemia & 2 \\
\hline Chronic myeloid leukemia & 1 \\
\hline Multiple myeloma & 1 \\
\hline Colonic cancer & 1 \\
\hline Bronchogenic carcinoma & 1 \\
\hline $\begin{array}{l}\text { CONNECTIVE } \\
\text { TISSUE }\end{array}$ & 11 \\
\hline Systemic lupus erythematosus & 6 \\
\hline $\begin{array}{l}\text { Mixed connective } \\
\text { disorders }\end{array}$ & 4 \\
\hline Takayasu arteritis & 14 \\
\hline MISCELLANEOUS & 1 \\
\hline HLH Syndrome & 3 \\
\hline Atrial myxoma & 1 \\
\hline Autoimmune Hepatitis & 1 \\
\hline UNDIAGNOSED & \\
\hline Self limiting & 11 \\
\hline Persistent & \\
\hline & \\
\hline
\end{tabular}

Laboratory procedures utilized for the final diagnosis

\begin{tabular}{|l|c|c|}
\hline Diagnostic methods & $\begin{array}{c}\text { No. of } \\
\text { cases }\end{array}$ & Percent \\
\hline NON INVASIVE & 58 & $67.5 \%$ \\
\hline Diagnostic blood tests & 15 & $17.4 \%$ \\
\hline Culture & 12 & $14 \%$ \\
\hline Radiology or Imaging & 9 & $10.5 \%$ \\
\hline Bone marrow aspirate/FNAC & 6 & $7 \%$ \\
\hline Theurapeutic Trial & 5 & $5.8 \%$ \\
\hline Clinical course & 11 & $12.8 \%$ \\
\hline INVASIVE & 28 & $32.5 \%$ \\
\hline Biopsy & 26 & $30.2 \%$ \\
\hline Arteriography & 2 & $2.3 \%$ \\
\hline
\end{tabular}

\section{Discussion}

Fevers of unknown origin remain one of the most difficult diagnostic challenges in medicine.PUO is caused by different etiologies despite different investigations, diagnosis could not be reached in some cases. This study aim is to find the causes of classical form of PUO around the studied patients. In our study total number of cases studied were 100.This sample size was similar to previous studies. 91 patients in Mir et al study, Petersdorf and Beeson studied 100 patients, Kejariwal et al. studied 100 patients, Bandyopadhya et al studied 164 patients.

In our study, definitive diagnosis was established in $86(86 \%)$ patients, whereas $14(14 \%)$ patients were discharged without establishing a definite diagnosis. The number of the undiagnosed cases in previous studies range from 7 to $30 \%$ in the study by Petersdorf and Beeson, $7-12 \%$ in Bandyopadhya et al, $14 \%$ in Kejariwal et al, $29 \%$ in Montasser et al.

In this study, infectious causes were the most common cause of PUO comprising $53 \%$. out of which Tuberculosis was the single most common infection (27\%).Bandyopadhyay D et al study conducted in Kolkata, Tuberculosis accounted for $28 \%$ of the cause of PUO out of which $72 \%$ were found to be extra pulmonary tuberculosis. In the series by Kejariwal et al, tuberculosis was again the commonest diagnosis.

In our study second most common infectious cause was Abscesses (10\%) followed by 
endocarditis (7\%), enteric fever $(5 \%)$, urinary tract infection $(4 \%)$.

In our study, hematological malignancies in the form of non-Hodgkin lymphoma was diagnosed in eight $(8 \%)$ patients, Hodgkin lymphoma in four (4\%) patients, acute myeloid leukemia in two (2\%)patients, and chronic myeloid leukemia was diagnosed in one $(1 \%)$ patient and multiple myeloma in one patient $(1 \%)$ and colonic cancer in one patient $(1 \%)$ and bronchogenic carcinoma in one patient $(1 \%)$.

Connective tissue disorders such as systemic lupus erythematosis were diagnosed in $\operatorname{six}(6 \%)$ patients and mixed connective tissue disorders in four patients(4\%), takayasu arteritis in one $(1 \%)$ patient.

Miscellaneous causes include Haemophagocytic lymphohistiocytosisin one patient $(1 \%)$, atrial myxoma (1\%), autoimmune hepatitis $(1 \%)$.

In Mir et al study 91 patients with classical PUO were selected. A definite diagnosis was established in $77 \%$ cases. Out of which infections acconted for $44 \%$ cases of PUO, followed by malignancies $12 \%$ of cases, and connective tissue disorders for $12 \%$ of the cases.

Montasser et al study showed that infections were main cause of PUO (66.3\%), followed by neoplasms $(7.2 \%)$, connective tissue disorders (7.2\%), $11.4 \%$ cases were diagnosed as miscellaneous (inflamatory bowel disease, Behcet disease, drug fever, familial mediterranean fever).

Barbado et al study showed that infectious diseases accounted for $31 \%$ of cases of PUO followed by neoplasms $(8.27 \%)$. out of $4.5 \%$ cases were Hodgkin's disease and $(3.75 \%)$ cases were non-Hodgkin's disease.

\section{Conclusion}

Infection especially tuberculosis was the most important cause of PUO in India, despite the decreasing importance of infections in western literature. The incidence of neoplasm was also high in this study when compared to previous studies from northern India. This trend needs further confirmation. The diagnosis was established by non invasive methods in more than two third of cases.

\section{Limitations}

The study is done in limited number of subjects in one region. Results may vary in a large number of subjects and various regions.

\section{Source of Funding: None \\ Conflicts of Interest: None}

\section{References}

1. Durack DT, Street AC. Fever of unknown origin: re-examined and redefined. In: Remington JS, Swartz MN, editors. Current clinical topics in infectious diseases: Boston Blackwell Science; 1991. p. 35.

2. Petersdorf RG, Beeson PB. Fever of unexplained origin: report on 100 cases. Medicine (Baltimore) 1961; 40:1-30.

3. Bleeker-Rovers CP, Vos FJ, Mudde AH, Dofferhoff AS, de Geus-oei LF, Rijnders $\mathrm{AJ}$, et al. A prospective multicenter study of the value of FDG-PET as part of a structured diagnostic protocol in patients with fever of unknown origin. Eur J Nucl Med Mol Imaging 2007; 34:694-703.

4. Beresford RW, Gosbell IB. Pyrexia of unknown origin: causes, investigation and management. Intern Med J 2016; 46:10111016.

5. Mir T, Dhobi GN, Koul AN, Saleh T. Clinical profile of classical FUO. Caspian J Intern Med 2014; 5:35-39.

6. Bandyopadhyay $\mathrm{D}$, Bandyopadhyay $\mathrm{R}$, Paul R, Roy D. Etiological study of fever of unknown origin in patients admitted to medicine ward of a teaching hospital of eastern India. J Glob Infect Dis 2011; 3:329-333.

7. Kejariwal D, Sarkar N, Chakraborti SK, Agarwal V, Roy S. Pyrexia of unknown origin: a prospective study of 100 cases. J Postgrad Med 2001; 47:104-107. 
8. Montasser MF, Abd-el-Kader NA, Montasser IF, El Khouly AM. Letter to the editor, Changing the face of fever of unknown origin in Egypt: a single hospital study. Braz J Infect Dis 2015; 19:334-335.

9. Barbado FJ, Vazquez JJ, Pena JM, Arnalich F, Ortiz-Vazquez J. Pyrexia of unknown origin: changing spectrum of diseases in two consecutive series. Postgrad Med J 1992; 68:884-887

10. Ogoina D. Fever, fever patterns and diseases called 'fever' - a review. J Infect Public Health 2011; 4:108-124.

11. Ogoina D. Fever, fever patterns and diseases called 'fever' - a review. J Infect Public Health 2011; 4:108-124. 